\title{
Characteristics of lactic acid bacteria isolated from palm sugar from West Sumatra, Indonesia and their potential as a probiotic
}

\author{
NURAZIZAH RAMADHANTI ${ }^{1}$, SRI MELIA ${ }^{2}$, JAMES HELLYWARD ${ }^{2}$, ENDANG PURWATI $^{2 \vee}$ \\ ${ }^{1}$ Program of Animal Science, Program of Graduates, Universitas Andalas. J1. Univ. Andalas, Limau Manis, Padang 25171, West Sumatra, Indonesia \\ ${ }^{2}$ Faculty of Animal Science, Universitas Andalas. J1. Univ. Andalas, Limau Manis, Padang 25171, West Sumatra, Indonesia. \\ Tel.: +62-751-71464, Fax.: +62-751-71464, "email: purwati17@ansci.unand.ac.id
}

Manuscript received: 21 March 2021. Revision accepted: 17 April 2021.

\begin{abstract}
Ramadhanti N, Melia S, Hellyward J, Purwati E. 2021. Characteristics of lactic acid bacteria isolated from palm sugar from West Sumatra, Indonesia and their potential as a probiotic. Biodiversitas 22: 2610-2616. Palm sugar is one of the sugar products from palm sap processing. It is made by reducing the water content in the sap to certain water content and is used as a natural sweetener. This study used palm sugar from 3 producers, i.e. Marapalam Gula Semut (MGS), Tetesan Gula Semut (TGS) and Sungayang Gula Semut (SGS) in Sungayang, West Sumatra, Indonesia. This study aimed to isolate and identify lactic acid bacteria (LAB) from palm sugar, potentially as a probiotic, using the 16S rRNA method. The probiotic potential of bacteria was selected based on morphology, biochemical properties, resistance to acidic $\mathrm{pH} 3$ and $0.3 \%$ bile salts, antimicrobial activity against pathogenic bacteria. The results showed that lactic acid bacteria isolated from palm sugar are Gram-positive rod-shaped (Bassil), negative catalase, and homofermentative. The total colonies of lactic acid bacteria ranged from $50 \times 10^{7} \mathrm{cfu} / \mathrm{g}-117 \times 10^{7} \mathrm{cfu} / \mathrm{g}$. The MGS lactic acid bacteria had $74.71 \%$ viability resistance in acidic $\mathrm{pH} 3,65.52 \%$ viability against bile salts $(0.3 \%$ ox gall). The diameter of inhibition against Escherichia coli $\mathrm{O} 157$ was $18.20 \mathrm{~mm}$, Propionibacterium acnes $(18.00 \mathrm{~mm})$, Acinetobacter baumannii $(14.19 \mathrm{~mm})$, and Listeria monocytogenes $(16.35 \mathrm{~mm})$. The phylogenetic tree based on 16S rRNA showed that the MGS isolate has a similarity of $99.92 \%$ to Lactobacillus fermentum strain 1743. It can be concluded that Lactobacillus fermentum strain 1743 isolated from palm sugar has potential as a probiotic.
\end{abstract}

Keywords: 16S rRNA, lactic acid bacteria, Lactobacillus fermentum strain 1743, palm sugar, probiotic

\section{INTRODUCTION}

Sugar palm (Arenga pinnata) is a plant whose parts can be used for human needs. Each palm sugar has a different sap composition containing water, sucrose, reducing sugar, other organic materials, and inorganic materials. Palm sugar contains high glucose and sucrose compared to sugar cane. Sap raw materials are cooked until brown and thickened, followed by cooling and crystallization. Crystallization is performed by stirring using a wooden spoon to form sugar crystals. After that, it is sifted continuously to obtain a uniform grain size until the granules pass through the sieve, and then, the sugar is packed.

BAL can use sucrose contained in palm sugar in order to support human health. According to Joseph and Layuk (2012), palm sugar has a high carbohydrate content, i.e., sucrose ranging from $75-86 \%$. Carbohydrate content in palm sugar is in the form of simple sugars, namely fructose and disaccharides. This sugar that undergoes glycolysis in aerobic condition produces pyruvate, but, glycolysis under anaerobic conditions produce lactic acid. The formation of lactic acid is caused by the lactase enzyme produced by lactic acid bacteria. Lactic acid bacteria are Gram-positive cocci, catalase-negative, and non-sporulating bacteria, and they produce lactic acid by fermenting glucose (Romadhon et al. 2012). Lactic acid bacteria are paired, or chainshaped, immobile, facultatively anaerobic, and mesophyll and are divided into several genera (Syukur and Purwati 2013). Lactic acid bacteria are important groups of probiotic bacteria, including Lactobacillus, Lactococcus, Streptococcus, Pediococcus, Carnobacterium, Enterococcus, Propionibacterium, and Leuconostoc (Kocabay and Cetinkaya 2020). Lactobacillus is the largest genus of lactic acid bacteria (LAB) with 183 species. It is a Grampositive bacteria shaped like rods that can ferment glucose and produce lactic acid (Zhang et al. 2016). Many studies have been carried out to identify and characterize lactic acid bacteria isolated from biological natural resources. Lactobacillus delbrueckii $\mathrm{KH} 3$ was isolated from palm sap (Manel et al. 2011), Lactobacillus fermentum L23 from buffalo milk (Melia et al. 2018), Lactobacillus plantarum Dad-13 from curd (Purwandhani et al. 2018) as well as Lactobacillus pentosus from okara (Aritonang et al. 2017).

Lactic acid bacteria can be used as a source of probiotics. According to FAO (2002), probiotics are living organisms that can provide health benefits and safe to be consumed as food supplements. Probiotic bacteria, which are widely known, are included in the lactic acid bacteria group and are safe microorganisms called food-grade microorganisms (Syukur and Purwati 2013). Lactic acid bacteria must have probiotic characteristics. Probiotics characteristics include antimicrobial activity, resistance to the digestive system such as gastric acid, bile, and pancreatic juices, having anticarcinogenic activity, colonizing the digestive tract, and being able to increase the 
ability of intestinal absorption (Syukur et al. 2011). Mojgani et al. (2015) stated that in general, probiotic bacteria must have essential properties such as resistance to the stomach and intestinal conditions, where acid and bile are factors affecting growth and survival. Isolation and identification of lactic acid bacteria from palm sugar are essential to be carried out to obtain new species of lactic acid bacteria from palm sugar. Also, the utilization of regional biological resource products will introduce regional specialties, especially West Sumatra.

\section{MATERIALS AND METHODS}

\section{Sampling}

This study used palm sugar from three different producers namely Marapalam Gula Semut (MGS), Tetesan Gula Semut (TGS) and Sungayang Gula Semut (SGS) in Nagari Andaleh Baruh Bukik, Sungayang Sub-District, Tanah Datar Regency, West Sumatra, Indonesia (Figure 1).

\section{Palm Sugar Production}

The raw material of palm sugar is sugar palm sap. The sap is provided and cooked for $8-10$ hours at $100^{\circ} \mathrm{C}$ until brown and thickened, followed by cooling at $40^{\circ} \mathrm{C}$ for 1 hour and crystallization. Crystallization was performed by stirring using a wooden spoon to form sugar crystals. After that, it was sifted with an 18 mesh sieve to uniform the grain size. Sugar granules that did not pass must be refined, and then, it was performed continuously until the granules passed through the sieve. Finally, the sugar was packed (Figure 2).

\section{Isolation and identification of Lactic Acid Bacteria}

Palm sugar was weighed as much as 1 gram, then put in a test tube containing $9 \mathrm{ml}$ of the MERCK de-Mann Rogosa Sharpe (MRS) broth solution, then it was vortexed until homogeneous. The result was called a $10^{-1}$ dilution, then was incubated for 24 hours in an incubator at $37^{\circ} \mathrm{C}$.
$100 \mu \mathrm{L}$ of the dilution was put into the Eppendorf tube containing $900 \mu \mathrm{L}$ of the MERCK de-Mann Rogosa Sharpe (MRS) broth solution. Furthermore, serial dilution was carried out up to $10^{-8}$. From a $10^{-8}$ dilution, $100 \mu \mathrm{L}$ of the sample was cultivated by the spread method on a Petri dish containing MRS Agar (MERCK), then it was flattened with a stick. The inoculum was stored in an anaerobic jar then incubated in an incubator for 48 hours at $37^{\circ} \mathrm{C}$. After 48 hours, a single colony of lactic acid bacteria was characterized. The isolate with yellowish-white slippery round was transferred to MRS Agar (MERCK) medium for colony purification using the streak method with ose needle, then incubated for 24 hours at $37^{\circ} \mathrm{C}$ (Shafakatullah and Chandra 2014).

\section{Biochemical properties test}

The Fermentative Type Test was carried out by inserting lactic acid bacteria isolates in $5 \mathrm{ml}$ of MERCK MRS Broth. Then, the Durham tube was inserted upside down. It was incubated for 48 hours at $37^{\circ} \mathrm{C}$. The presence of air bubbles in the Durham tube was observed (Rashid et al. 2014).

The catalase test was carried out by taking out lactic acid bacteria using a loop needle and then scratched on the object-glass. It was dripped with $3 \%$ hydrogen peroxide $\left(\mathrm{H}_{2} \mathrm{O}_{2}\right)$ using a $50 \mu \mathrm{L}$ pipette, and gas presence was observed (Public Health England 2014).

\section{Acid resistance test}

Five hundred $\mu \mathrm{l}$ of enriched LAB culture was inserted into a test tube containing $4.5 \mathrm{ml}$ MRS Broth and then added with several drops of HCL to get $\mathrm{pH}$ three as the $\mathrm{pH}$ of stomach acid. The solution was diluted to a $10^{-6}$ dilution, then $100 \mu \mathrm{l}$ of dilution was cultivated on a petri dish containing MRS agar medium. It was incubated for 48 hours. After incubation, the number of colonies and their viability were calculated (Sunaryanto and Marwoto 2013).
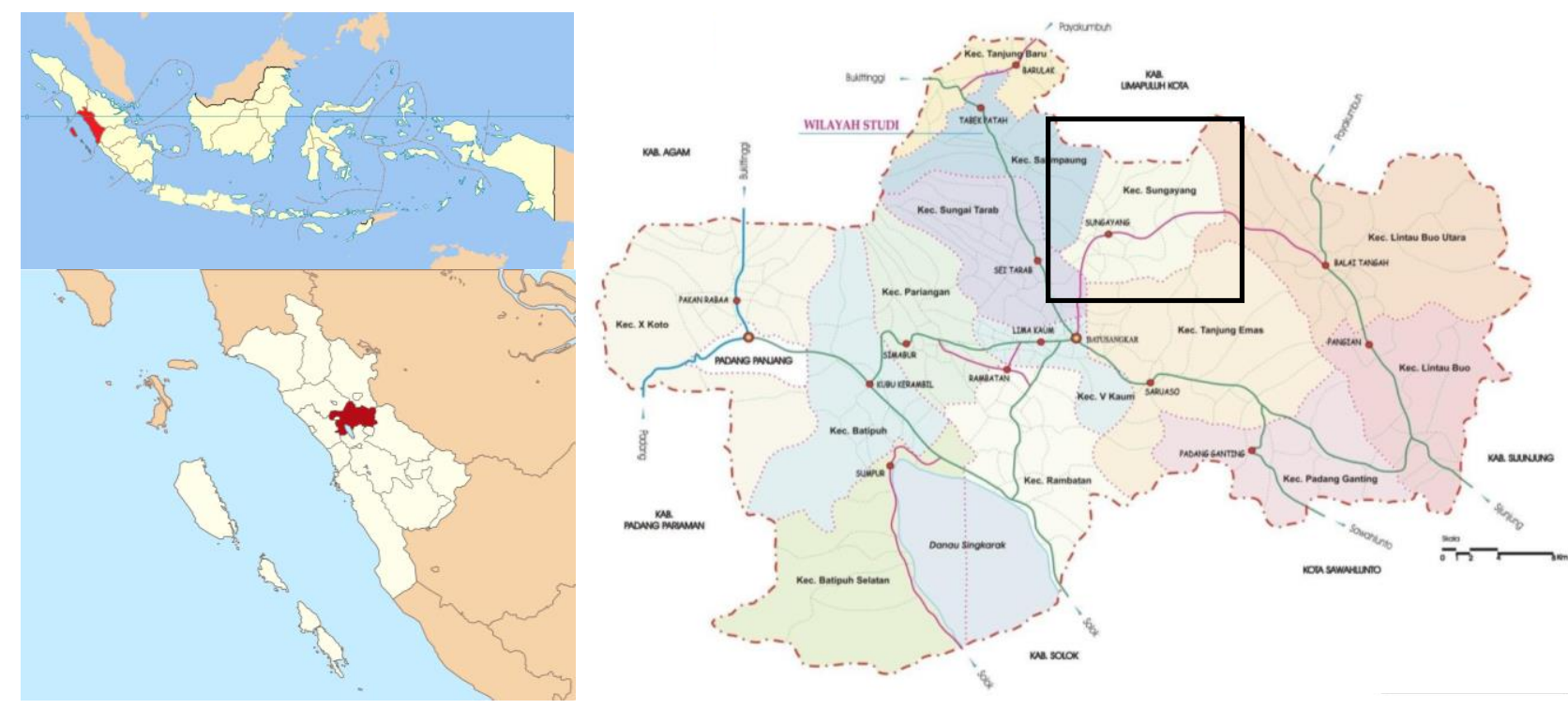

Figure 1. Map of Sungayang Sub-district (box), Tanah Datar District, West Sumatra Province, Indonesia $\left(3^{\circ}-30^{\circ} \mathrm{S}, 98^{\circ}-101^{\circ} \mathrm{E}\right)$ 


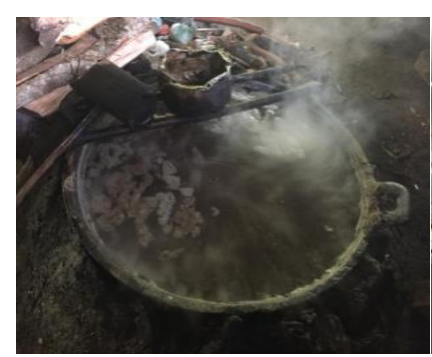

A

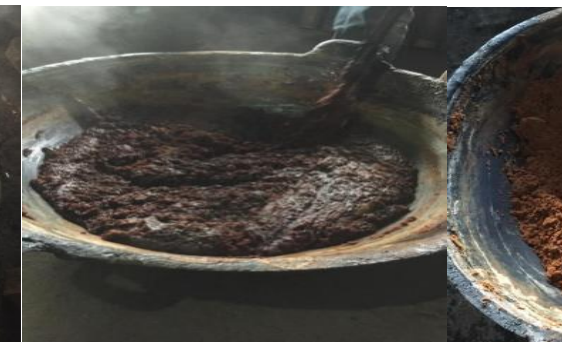

B

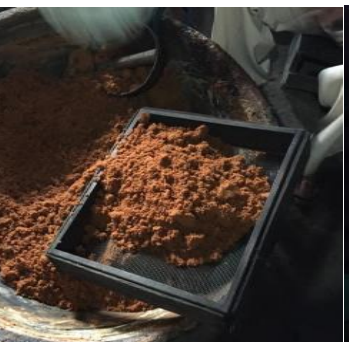

C

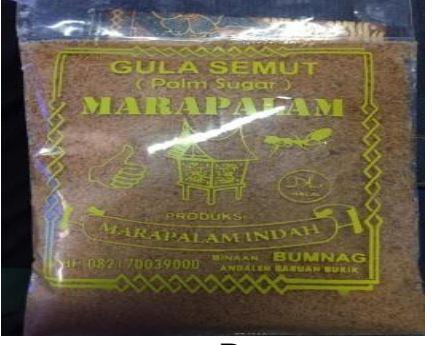

D

Figure 2. Palm sugar processing: A. Cooked sap, B. Stirring until brown and thickened, C. Sieved and filtered, D. Packed palm sugar

\section{Bile salt resistance test}

One $\mathrm{ml}$ of bacterial culture was inoculated in $9 \mathrm{ml}$ of MRS Broth and incubated at $37^{\circ} \mathrm{C}$ for 24 hours. Furthermore, $1 \mathrm{ml}$ of bacterial culture from MRS Broth was inserted into a test tube containing $9 \mathrm{ml}$ of MRS Broth solution without ox gall (control) and in MRS Broth with $0.3 \%$ ox gall for 24 hours. Cultures with and without $0.3 \%$ ox gall (control) were diluted to $10^{-6}$ and planted by spread method onto MRS agar medium and incubated at $37^{\circ} \mathrm{C}$ for 48 hours. The number of viable bacteria was calculated as Colony Forming Units (CFU). After that, the LAB viability was calculated (Sunaryanto and Marwoto 2013).

\section{Antimicrobial and antibiotic activity}

The well-diffusion test carried out the antimicrobial activity test. Cell-free supernatant was obtained from lactic acid bacteria grown in MRS Broth (MERCK) for 24 hours at $37{ }^{\circ} \mathrm{C}$ under anaerobic conditions and centrifuged at $10,000 \mathrm{rpm}$ for 5 minutes at $4^{\circ} \mathrm{C}$. Fifty $\mu \mathrm{L}$ of the supernatant was inserted into the well $(6 \mathrm{~mm})$, punched with a cork borer in Nutrient Agar. Nutrient agar has been inoculated previously with $0.2 \%$ of pathogenic bacteria. As a control, it was compared with antibiotics (penicillin 10 $\mu \mathrm{g}$, kanamycin $30 \mu \mathrm{g}$, ampicillin $10 \mu \mathrm{g}$ ). The clear zone was observed after 24 hours of incubation (Yang et al. 2012).

\section{Molecular Identification of Lactic Acid Bacteria using 16S rRNA}

Lactic acid bacteria were cultured in MRS broth at $37^{\circ} \mathrm{C}$ for 24 hours. Genomic DNA isolation was carried out using Extrap Soil DNA Kit Plus Ver.2. The polymerase chain reaction (PCR) amplification of $16 \mathrm{~S}$ rRNA isolates used 16S rRNA gene fragments of $\sim 1.5 \mathrm{~KB}$ as universal primers. Initial denaturation was carried out at $95^{\circ} \mathrm{C}$ for 5 minutes with 25 cycles, followed by denaturation at $94^{\circ} \mathrm{C}$ for 1 minute. Annealing was carried out at $56^{\circ} \mathrm{C}$ for 1 minute, extension at $72^{\circ} \mathrm{C}$ for 1.5 minutes, and a final extension at $72^{\circ} \mathrm{C}$ for 7 minutes. The resulting DNA was separated using electrophoresis at $100 \mathrm{~V}$ for 21 minutes using $1 \%$ agarose in $\times 1$ TAE buffer. A gel washer documentation system was used to generate an image of the tape on the gel. Purification was performed using a rapid gene gel/PCR extraction kit (Nippon Genetics, Germany). The sequences were analyzed using the BLAST program in the NCBI gene bank database available at http://blast.ncbi.nlm.nih.gov/Blast.cgi. The sequence alignment was made using the Bioedit application, and the phylogenetic tree was created using the MEGA 6 application.

\section{RESULTS AND DISCUSSION}

\section{Morphological Identification of Lactic Acid Bacteria}

The density of lactic acid bacteria in MGS palm sugar was $117 \times 10^{7} \mathrm{CFU} / \mathrm{g}$, TGS palm sugar was $76 \times 10^{7} \mathrm{CFU} / \mathrm{g}$, and SGS palm sugar was $50 \times 10^{7} \mathrm{CFU} / \mathrm{g}$. According to the FAO criteria (2002), the colony yield of lactic acid bacteria should be $10^{6}-10^{8} \mathrm{CFU} /$ gram. Lactic acid bacteria isolated from palm sugar were yellowish-white with circular colony shapes and raised elevations (Table 1); however, Juliyarsi et al. (2018) found that lactic acid bacteria's characters were circular, creamy white, and raised in MRS agar.

Furthermore, the lactic acid bacteria were observed microscopically for Gram stain. Gram stain determines bacteria as Gram-positive or Gram-negative. It is indicated by the ability of bacteria to absorb color reagent. The Gram staining results showed that bacteria isolated from MGS, TGS, and SGS palm sugars were rod-shaped and Grampositive. Bacteria treated with crystal violet that remain purple although washed with alcohol and exposed to red safranin are Gram-positive bacteria, while Gram-negative bacteria will turn red (Unus 2005). Lactic acid bacteria have the characteristics of Gram-positive, rod-shaped or round, facultatively anaerobic, nonsporulating, and produce lactic acid bacteria as the main product of carbohydrate fermentation (glucose, fructose, and sucrose) (Salminen et al. 2004).

\section{Biochemical properties}

The biochemical test results showed that bacteria isolated from palm sugar are catalase-negative and homofermentative (Table 2). A negative catalase reaction was indicated by the absence of bubbles, which means that there is no formation of oxygen gas due to $\mathrm{H}_{2} \mathrm{O}_{2}$ breakdown by the catalase enzyme produced by bacteria. A previous study by Yelnetty et al. (2014) showed that there are 26 isolates from goat milk with spontaneous fermentation, and there is a negative catalase reaction. Homofermentative was indicated by the absence of bubbles in the Durham tube. It is in line with a study by Melia et al. (2019) that the lactic acid bacteria Pediococcus acidilactici PB22 strain is a homofermentative isolate. 


\section{Resistance of Lactic Acid Bacteria to acidic conditions}

The viability of lactic acid bacteria to acidic conditions (pH 3) was in the range of $48.39-74.71 \%$ (Table 3). Each isolate has different viability because each isolate has a different ability to survive at gastric $\mathrm{pH}$ (acid). MGS had the highest viability of $74.71 \%$. Lactic acid bacteria, which have the potential as probiotic, must be resistant to gastric $\mathrm{pH}$, ranging from 2-3, caused by the secretion of gastric juices. The viability of lactic acid bacteria isolated from milk and cow dung at $\mathrm{pH} 3$ ranged from $61.44-81.25 \%$ (Jain et al. 2017). Melia et al. (2018) showed that the lactic acid bacteria isolate Lactobacillus fermentum strain L23 can survive at pH 2 with viability of 55.64-73.94\%. Lactic acid bacteria from palm sugar have higher viability than Lactobacillus rhamnosus from buffalo milk from Karnataka, India, with $30 \%$ viability at pH 3 for 3 hours (Shafakatullah and Chandra 2014). The population density of lactic acid bacteria with potential probiotics must be > $10^{6} \mathrm{CFU} /$ gram after incubation at pH 3.0 (Azat et al. 2016). It indicates the survival rate of lactic acid bacteria in the $\mathrm{pH}$ of the digestive tract. Harun et al. (2020) stated that the higher the lactic acid bacteria's viability, the higher the resistance of bacteria or isolates of lactic acid bacteria to gastric $\mathrm{pH}$.

\section{The resistance of Lactic Acid Bacteria to bile salt}

Lactic acid bacteria from palm sugar was tested against $0.3 \%$ bile salts for 4 hours. The result showed that the viability ranged from 30.43 to $65.52 \%$, with the highest viability was MGS isolate (Table 4). This study indicated that the LAB isolate from palm sugar could live at a concentration of bile salts of $0.3-0.5 \%$ as in the human body. The viability of LAB from palm sugar in $0.3 \%$ bile salts after 4 hours of incubation was varied (Table 4). MGS isolate had a viability of $65.52 \%$ under the bile salts conditions. It showed that MGS could survive better than TGS and SGS. The higher the bacterial viability obtained, the higher the resistance of probiotic bacteria to bile salts. An effective probiotic must be able to withstand the conditions of bile salts secreted by the liver. Bile salts reduce the number of bacteria by destroying their cell walls. MGS isolates had higher viability than Lactobacillus fermentum strain IMAU70167 isolated from buffalo milk with $32.23-56.13 \%$ viability in $0.3 \%$ bile salts for 4 hours (Melia et al. 2018). Anandharaj and Sivasankari (2014) found that Lactobacillus oris strain HM168 isolated from breast milk had a viability of $20.1-26.9 \%$ at $0.3 \%$ ox gall for 3 hours. The lactic acid bacteria strains isolated from buffalo milk in Karnataka, India can survive at bile salts concentrations of $0.3 \%$ and $0.5 \%$ bile salts but did not survive at $1 \%$ (Shafakatullah and Chandra 2014). According to Harun et al. (2020), lactic acid bacteria's resistance to bile salts is related to the enzyme Bile Salt Hydrolase (BSH), which hydrolyze conjugated bile salts, thereby reducing the toxic effect on cells.

\section{Antimicrobial activity of Lactic Acid Bacteria}

The highest resistance to acids and bile salts of MGS lactic acid bacteria was selected for antimicrobial activity against pathogenic bacteria. MGS lactic acid bacteria had a clear zone against E. coli $0157 \quad(18.20 \quad \mathrm{~mm})$, Propionibacterium acnes (18.00 mm), Acinetobacter baummannii $(14.19 \mathrm{~mm})$, and Listeria monocytogenes (16.35 mm) (Table 5).

Escherichia coli $\mathrm{O} 157$ was the most sensitive to MGS isolate with a clear zone diameter of $18.20 \mathrm{~mm}$. The diameter of MGS inhibition against E. coli O157 was higher than the inhibition of the lactic acid bacteria isolated from tempoyak (12 mm) (Juliyarsi et al. 2018). However, the MGS inhibition diameter against Listeria monocytogenes was relatively lower than Lactobacillus fermentum strain L-23 isolated from Agam buffalo milk (19 mm) (Melia et al. 2017). MGS inhibition was higher than Pediococcus acidilactici strain PB22 isolate from Bekasam (5.10 mm) (Melia et al. 2019) and has been applied in the manufacture of yogurt probiotic (Melia et al. 2020). The inhibition zone of MGS against Acinetobacter baummannii was relatively low $(14.19 \mathrm{~mm})$, but it was higher than Lactobacillus rhamnosus GG (11.76 $\mathrm{mm})$ (Dallal et al. 2017).

Pan et al. (2009) categorized the antibacterial activity based on the diameter of the clear zone as follows: low antimicrobial activity (0-3 mm), moderate antimicrobial activity (> 3-6 mm), and high antimicrobial activity (> 6 $\mathrm{mm})$. Some lactic acid bacteria had antimicrobial activity against L. monocytogenes and also have probiotic potential. Organic acids and hydrogen peroxide produced by lactobacilli can inhibit the growth of Gram-positive and Gram-negative bacteria, while bacteriocin has more effect on Gram-positive bacteria (Vasiee et al. 2014). Lactic acid bacteria produce lactic acid, the main glucose fermentation product (Arena et al. 2017).

Table 1. Macroscopic identification of lactic acid bacteria isolates

\begin{tabular}{lllll}
\hline $\begin{array}{l}\text { LAB } \\
\text { isolate }\end{array}$ & Color & $\begin{array}{l}\text { Colony } \\
\text { form }\end{array}$ & Margin & Elevation \\
\hline MGS & Yellowish-white & Circular & Entire & Raised \\
TGS & Yellowish-white & Circular & Entire & Raised \\
SGS & Yellowish-white & Circular & Entire & Raised \\
\hline
\end{tabular}

Notes: MGS (Marapalam Gula Semut ), TGS (Tetesan Gula Semut), SGS (Sungayang Gula Semut)

Table 2. Catalase test and fermentation type of lactic acid bacteria isolates from palm sugar

\begin{tabular}{lll}
\hline LAB isolate & Catalase test & Fermentation type \\
\hline MGS & Negative (-) & Homofermentative \\
TGS & Negative (-) & Homofermentative \\
SGS & Negative (-) & Homofermentative \\
\hline
\end{tabular}

Table 3. The viability of Lactic Acid Bacteria from palm sugar at acidic conditions

\begin{tabular}{lccc}
\hline \multirow{2}{*}{ LAB isolate } & \multicolumn{2}{c}{$\begin{array}{c}\text { Number of colonies } \\
\text { (CFU/gram) }\end{array}$} & Viability (\%) \\
\cline { 2 - 3 } & $\mathbf{p H ~ c o n t r o l}$ & $\mathbf{p H ~ 3}$ & \\
\hline MGS & $87 \times 10^{7}$ & $65 \times 10^{7}$ & 74.71 \\
TGS & $68 \times 10^{7}$ & $40 \times 10^{7}$ & 58.82 \\
SGS & $62 \times 10^{7}$ & $30 \times 10^{7}$ & 48.39 \\
\hline
\end{tabular}


Table 4. The viability of Lactic Acid Bacteria isolated from sugar palm to bile salts

\begin{tabular}{cccc}
\hline \multirow{2}{*}{$\begin{array}{c}\text { LAB } \\
\text { isolate }\end{array}$} & \multicolumn{2}{c}{$\begin{array}{c}\text { Number of colonies } \\
\text { (CFU/gram) }\end{array}$} & \multirow{2}{*}{ Viability (\%) } \\
\cline { 2 - 3 } & Control & $\mathbf{0 . 3 \%}$ Oxgall & \\
\hline MGS & $87 \times 10^{7}$ & $57 \times 10^{7}$ & 65,52 \\
TGS & $68 \times 10^{7}$ & $37 \times 10^{7}$ & 54,41 \\
SGS & $62 \times 10^{7}$ & $25 \times 10^{7}$ & 30,43 \\
\hline
\end{tabular}

Table 5. The clear zone diameter of MGS lactic acid bacteria against 4 pathogenic bacteria

\begin{tabular}{ccccc}
\hline \multirow{2}{*}{$\begin{array}{c}\text { Inhibition } \\
\text { Source }\end{array}$} & \multicolumn{4}{c}{ The diameter of the clear zone $(\mathbf{m m})$} \\
\cline { 2 - 5 } & $\mathbf{0 1 5 7}$ & $\begin{array}{c}\boldsymbol{P} \text { acnes } \\
\text { Maummannii }\end{array}$ & $\begin{array}{c}\boldsymbol{A} \text {. } \\
\text { monocytogenes }\end{array}$ \\
\hline MGS & 18.20 & 18.00 & 14.19 & 16.35 \\
Ampicillin & - & - & 5.05 & - \\
Kanamycin & 14.95 & 16.80 & 15.20 & 14.10 \\
\hline
\end{tabular}

\section{Results of 16S rRNA amplification using PCR}

Amplification of the 16S rRNA gene isolate of MGS lactic acid bacteria from palm sugar was presented in Figure 3. PCR fragment size of 1542 bp used R Primer (16S-1492R, Tm $47^{\circ} \mathrm{C}, 5^{\prime}$-GTT TAC CTT GTT ACT ACT-3 $)$ and $\mathrm{F}\left(16 \mathrm{~S}-27 \mathrm{~F}, \mathrm{Tm} 54,3^{\circ} \mathrm{C}, 5^{\prime}\right.$-AGA GTT TGA TGCC CTC AG-3').

The phylogenetic tree based on the 16S rRNA gene sequence can be seen in Figure 4. The sequencing of palm sugar isolates was compared with Gen Bank data using the BLAST program on the NCBI website (http://www.ncbi.nlm.nih.gov), showing a similarity level of $99.93 \%$ with the Lactobacillus fermentum strain 1743. Therefore, it can be concluded that the MGS lactic acid bacteria isolated from the palm sugar is L. fermentum strain 1743. This lactic acid bacteria isolate a new strain found in palm sugar.

In conclusion, the lactic acid bacteria isolated from palm sugar had a total colony of $50 \times 10^{7} \mathrm{CFU} / \mathrm{g}-117 \mathrm{x}$ $10^{7} \mathrm{CFU} / \mathrm{g}$ in rod-shaped, Gram-positive, catalase-negative, and homofermentative. The MGS lactic acid bacteria isolated from palm sugar in Marapalam Sugar Ant (MGS) had the viability of $74.1 \%$ at $\mathrm{pH} 3,65.52 \%$ in $0.3 \%$ bile salts, and the highest antimicrobial activity against $E$. coli O157 with an inhibition zone of $18.20 \mathrm{~mm}$. The phylogenetic tree results based on 16S rRNA, MGS isolates from the producer Marapalam Sugar Ants in Sungayang Tanah Datar District were identified Lactobacillus fermentum strain 1743.

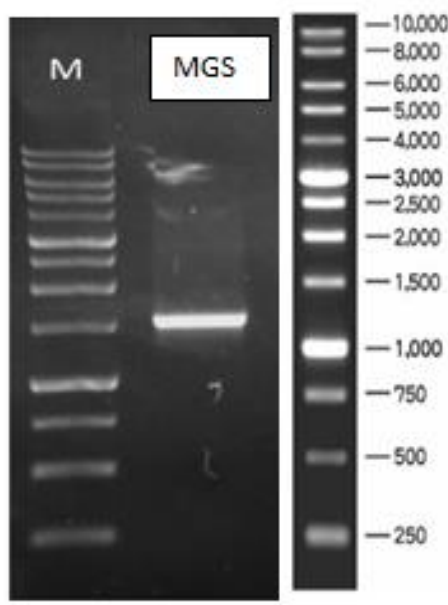

Figure 3. PCR amplification of ribosomal RNA using 11492R and $27 \mathrm{~F}$. MGS is a lactic acid bacteria isolated from palm sugar

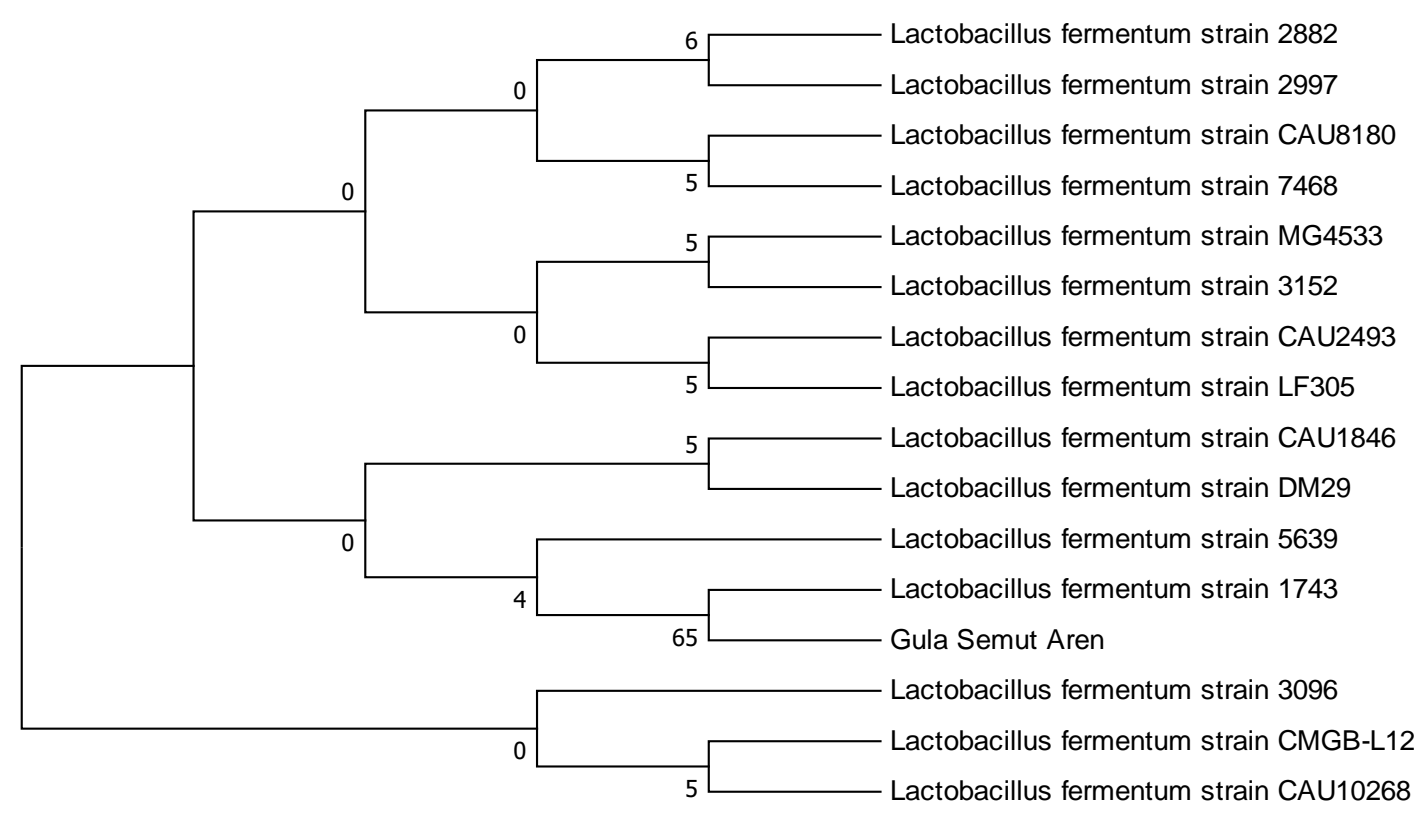

Figure 4. Phylogenetic Tree of Lactobacillus fermentum strain 1743 


\section{ACKNOWLEDGEMENTS}

This study was supported by the Laboratory of Livestock Products Technology, Faculty of Animal Husbandry, Andalas University, Padang, Indonesia. The author would like to thank the Institute for Community Service Research (LPPM) Andalas University through the excellent basic research scheme for professor publication research clusters with contract number T/15/UN.16.17/ PT.01.03/KO-PDU-KRPIGB/2020, to Prof. Endang Purwati.

\section{REFERENCES}

Arena MP, Capozzi V, Spano G, Fiocco D. 2017. The potential of lactic acid bacteria to colonize biotic and abiotic surfaces and the investigation of their interactions and mechanisms. Appl Microbiol Biotechnol 101: 2641- 2657. DOI: 10.1007/s00253-017-8182-z

Anandharaj M, Sivasankari B. 2014. Isolation of potential probiotic Lactobacillus oris HMI68 from mother's milk with cholesterolreducing property. $\mathrm{J}$ Biosci Bioeng 118: 153-9. DOI 10.1016/j.jbiosc.2014.01.015

Aritonang SN, Roza E, Rossi E, Purwati E, Husmaini. 2017. Isolation and identification of lactic acid bacteria from okara and evaluation of their potential as candidate probiotics. Pak J Nutr 16: 618-628. DOI: 10.3923/pjn.2017.618.628

Azat R, Liu Y, Li W, Kayir A. 2016. Probiotic properties of lactic acid bacteria isolated from traditionally fermented Xinjiang cheese. J Zhejiang Univ Sci B Biomed Biotechnol 17: 597-609. DOI: 10.1631/jzus.B1500250

Dallal SMM, Davoodabadi A, Abdi M, Hajiabdolbaghi M, Sharifi Yazdi MK, Douraghi M, Tabatabaei BSM. 2017. Inhibitory effect of Lactobacillus plantarum and Lactobacillus fermentum isolated from the faeces of healthy infants against non fermentative bacteria causing nosocomial infections. New Microb New Infect 15: 9-13. DOI 10.1016/j.nmni.2016.09.003

Food and Agriculture Organization of United Nations \& Organization (FAO). 2002. Guidelines for the evaluation of probiotics in food Report of a Joint FAO/WHO Working Group on Drafting Guidelines for the Evaluation of Probiotics in Food. London, London Ontario.

Harun H, Wirasti Y, Purwanto B, Purwati E. 2020. Characterization of lactic acid bacteria and determination of antimicrobial activity in dadih from Air Dingin Alahan Panjang District, Solok Regency-West Sumatera. Sys Rev Pharm 11: 583-586.

Jain N, Mehta A, Bharti V. 2017. Screening, characterization and in vitro evaluation of probiotic of Lactobacillus strains. Asian J Pharm Clin Res 10: 288-93. DOI: 10.22159/ajpcr.2017.v10i8.14233

Juliyarsi I, Hartini P, Yuherman, Djamaan A, Arief, Purwanto H, Aritonang SN, Hellyward J, Purwati E. 2018. Characterization of lactic acid bacteria and determination of antimicrobial activity in tempoyak from Padang Pariaman District, West Sumatra, Indonesia. Pak J Nutr 17: 506-511. DOI: 10.3923/pjn.2018.506.511

Joseph GH, Payung L. 2012. Pengolahan glanular gula dari gula semut aren. Jurnal B Palma 12: 60-65. [Indonesian]

Kocabay S, Cetinkaya S. 2020. Probiotic properties of Lactobacillus fermentum isolated from new-born faeces. J Oleo Sci 12: 1579-1584. DOI: 10.5650/jos.ess20224

Melia S,_Purwati E, Yuherman, Jaswandi, Aritonang SN, Silaen M. 2017 Characterization of the antimicrobial activity of lactic acid bacteria isolated from buffalo milk in West Sumatera (Indonesia) against Listeria monocytogenes. Pak J Nutr 16: 645-650. DOI: 10.3923/pjn.2017.645.650

Melia S, Yuherman, Jaswandi, Purwati E. 2018. Selection of buffalo milk, lactic acid bacteria with probiotic potential. Asian J Pharm Clin Res 11: 186-189. DOI: 10.22159/ajpcr.2018.v11i6.24809
Melia S, Ferawati, Yuherman, Jaswandi, Purwanto H, Purwati E. 2018. Probiotic characterization of lactic acid bacteria isolated from raw milk (buffalo, cow, and goat) from West Sumatera, Indonesia. Asian J Microbiol Biotechnol Environ Sci 20 : S131-S139.

Melia S, Purwati E, Kurnia YF, Pratama DR. 2019. Antimicrobial potential of Pediococcus acidilactici from Bekasam, fermentation of sepat rawa fish (Tricopodus trichopterus) from Banyuasin, South Sumatra, Indonesia. Biodiversitas J 20: 3532-3538. DOI: 10.13057/biodiv/d201210

Melia S, Juliyarsi I, Kurnia YF, Pratama YE, Pratama DR. 2020. The quality of fermented goat milk produced by Pediococcus acidilactici BK01 on refrigerator temperature. Biodiversitas 21 (10): 4591-4596. DOI: 1013057/biodiv/d211017

Manel Z, Sana M, Nedia K, Moktar H, Ali F. 2011. Microbiological analysis and screening of lactic acid bacteria from Tunisian date palm sap. Afr J Microbiol Res 5: 2929-2935. DOI: 10.5897/AJMR11.325

Mojgani N, Hussaini F, Vaseji N. 2015. Characterization of indigenous Lactobacillus strains for probiotic properties. Jundishapur J. Microbiol 8: 1-6. DOI: 10.5812/jjm.17523

Pan X, Chen F, Wu T, Tang H, Zhao Z. 2009. The acid, bile tolerance and antimicrobial property of Lactobacillus acidophilus NIT. Food Control 20: 598-602. DOI: 10.1016/j.foodcont.2008.08.019

Public Health England. 2014. Identification of Staphylococcus Species, Micrococcus Species and Rothia Species. UK Standards for Microbiology Investigations, UK.

Purwandhani SN, Utami T, Milati R, Rahayu ES. 2018. Isolation, characterization and screening of folate-producing bacteria from traditional fermented food (Dadih). Int Food Res J 25: 566-572.

Rashid S, Hassanshahian M. 2014. Screening, isolation and identification of lactic acid bacteria from a traditional dairy product of Sabzevar, Iran. Int J Enteric Pathog 2: e18393. DOI: 10.17795/ijep18393.

Romadhon, Subagiyo, Margino S. 2012. Isolasi dan karakterisasi bakteri asam laktat dari usus udang penghasil bakteriosin sebagai agen antibakteria pada produk-produk hasil perikanan. Jurnal Saintek Perikanan 8: 59-64. [Indonesian]

Salminen S, Wright AV, Ouwehand A. 2004. Lactic Acid Bacteria: Microbiology and Functional Aspects. 3rd edition. Revised and Expanded Marcel Dekker Inc, New York.

Sunaryanto R, Marwoto B. 2013. Isolasi, identifikasi, dan karakterisasi bakteri asam laktat dari dadih susu kerbau. Jurnal Sains dan Teknologi Indonesia 14: 228-233. DOI: 10.29122/jsti.v14i3.931. [Indonesian]

Shafakatullah N, Chandra M. 2014. Screening of raw buffalo's milk from Karnataka for potential probiotic strains. Res J Recent Sci 3: 73-78.

Syukur S, Utami LS, Purwati E, Urnemi Jamsari. 2011. Screening and in vitro antimicrobial, protease activities from West Sumatera, Indonesia, Proceedings of the International Seminar on HKI, Pekanbaru, 17-21 Juli 2011. [Indonesian]

Syukur S, Purwati E. 2013. Bioteknologi Probiotik untuk Kesehatan Masyarakat. Penerbit Andi, Yogyakarta. [Indonesian]

Unus. 2005. Basic Microbiology. Publisher Papas Sinar Sinanti, Jakarta. [Indonesian]

Vasiee AR, Tabatabaei YF, Mortazavi A, Edalatian MR. 2014. Isolation, identification and characterization of probiotic Lactobacilli spp. from Tarkhineh. Intl Food Res J 21: 2487-2492.

Yang E, Fan L, Jiang Y, Doucette C, Fillmore S. 2012. Antimicrobial activity of bacteriocin-producing lactic acid bacteria isolated from cheeses and yoghurts. AMB Expr 2: 48. DOI: 10.1186/2191-0855-248.

Yelnetty A, Purnomo, Purwadi, Mirah A. 2014. Biochemical characteristics of lactic acid bacteria with proteolytic activity and capability as starter culture isolated from spontaneous fermented local goat milk. J Nat Sci Res 4: 137-146.

Zhang B, Wang Y, Tan Z, Li Z, Jiao Z. 2016. Screening of probiotic activities of Lactobacilli strains isolated from traditional Tibetan qula, a raw yak milk cheese. Asian Australas J Anim Sci 29: 1490-1499. DOI: 10.5713/ajas.15.0849. 